\title{
PERBEDAAN SELF ASSESSMENT DAN PEER ASSESSMENT TERHADAP KOMPETENSI PEMASANGAN INFUS DITINJAU DARI MOTIVASI
}

Aan Devianto ${ }^{1}$, AA. Soebiyanto ${ }^{2}$, Hari Wujoso ${ }^{3}$

${ }^{1}$ STIKes Guna Bangsa Yogykarta, ${ }^{2,3}$ Program Studi Magister Kedokteran Keluarga, Program

Pascasarjana, Universitas Sebelas Maret Surakarta

\begin{abstract}
Background: There are different assessment methods that aim to evaluate the learning process of students, such as formative or summative methods. The assessment methods that are still rarely used in nursing education are self-assessment and peer assessment. Therefore, in order to determine whether these methods have advantages or disadvantages, investigation is needed. The research that is conducted with these methods is a research on the competencies on infusion installment that is also assessed from the students' motivation to follow the learning process.

Subjects and Methods : This research is a quantitative research using true experimental approach. The population is the students. The samples are obtained by using random sampling. The independent variables in this study are a self -assessment, peer assessment and motivation, while the dependent variable is the infusion installment competency. There are three purposes of this study. The first is to analyze the differences in self-assessment and peer-assessment of infusion installment competence. The second is to analyze the differences of motivation on infusion installment competence. The last is to analyze the interaction between the assessment of the competence models and the level of motivation on infusion installment. Two-path analysis of variance (ANOVA) was used to test statistical data.

Results: The results showed that there were significant differences between self-assessment and peer-assessment of competence on infusion installment with the results of $p=0.000$. Other results also showed a significant difference between high motivation and low motivation on infusion installment competence with the results of $p=0.002$. In addition to that, the statistical test also showed the interaction between the models of the assessment and the motivation on infusion installment competence with $p=0.000$. Additionally, there are also some treatment groups that were not significant with $\mathrm{p}=$ scores $>0.05$.
\end{abstract}

Keywords : Peer assessment, self -assessment, motivation, infusion installment

\section{PENDAHULUAN}

Dunia pendidikan memiliki berbagai macam metode evaluasi yang bertujuan untuk mengevaluasi proses belajar mengajar siswa, baik yang bersifat formatif maupun sumatif sesuai dengan kompetensinya, salah satu macam metode penilaian dalam pendidikan keperawatan adalah self assessment dan peer assessment (Zulharman, 2007).

Self assessment adalah peran siswa dalam mengidentifikasi kriteria atau standar untuk diterapkan dalam belajar dan membuat keputusan mengenai pencapaian kriteria atau standar tersebut, self assessment juga dapat digunakan untuk membantu mahasiswa dalam mengembangkan kemampuan menilai dan mengkritisi proses dan hasil belajarnya, membantu mahasiswa menentukan kriteria untuk menilai hasil belajarnya, dan sebagai syarat yang diperlukan dalam sebuah proses pembelajaran untuk memutuskan kelulusan (Boud 1995, Zulharman 2007).

Menurut Isaacs (1999), self assessment juga membantu mengembangkan kemampuan siswa dalam menilai pekerjaannya sendiri, meningkatkan mutu belajar dengan melihat kekurangan dan kelebihan waktu yang lampau, memberikan umpan balik atas siswa tanpa membebani pekerjaan pendidik, dan salah satu cara untuk menentukan nilai dan tingkat kemampuan siswa untuk tujuan sumatif. Suwandi (2009), mengatakan self assessment adalah suatu teknik penilaian yang mana peserta didik diminta untuk menilai dirinya sendiri yang berkaitan dengan status, proses dan tingkat pencapaian kompetensi yang dipelajarinya dalam mata kuliah tertentu.

Selain metode self assessment, terdapat juga metode penilaian peer assessment, metode ini menurut Zulharman (2007) dapat digunakan untuk membantu pelajar dalam mengembangkan kemampuan bekerjasama, mengkritisi proses dan hasil belajar orang lain (penilaian formatif), menerima feedback atau kritik dari orang lain, memberikan pengertian yang mendalam kepada para siswa tentang kriteria yang digunakan untuk menilai proses dan hasil belajar dan untuk penilaian sumatif. Menurut ( Brown et al. 1994, Zariski 1996, Race 1998) keuntungan dari self dan peer assessment 
adalah mendorong mahasiswa untuk memiliki rasa tanggung jawab terhadap proses belajarnya sehingga mahasiswa dapat mandiri, melatih evaluation skill yang berguna untuk life long learning dan mendorong deep learning.

Agar tercapai standar kompetensi sebagai seorang perawat yang profesional bukan hanya melalui pembelajaran yang dilakukan di dalam kelas saja, akan tetapi haruslah mempunyai laboratorium yang memadai untuk tempat mahasiswa melakukan praktikum untuk mengasah kompetensi yang diharapkan sehingga nantinya dapat mempunyai lulusan mahasiswa yang benar benar mempunyai kompetensi yang professional AIPNI (2008). Dari sekian banyak kompetensi keperawatan yang dipelajari, salah satu kompetensi keperawatan yang selama ini di anggap menjadi kompetensi yang sangat sulit untuk dipelajari adalah kompetensi pemasangan infus.

Data Stikes Guna Bangsa Yogyakarta (2012), tentang tingkat kelulusan mahasiswa S1 Keperawatan Stikes Guna Bangsa Yogyakarta pada kompetensi pemasangan infus pada tahun 2010, dari 50 mahasiswa yang dinyatakan lulus ujian praktikum adalah 10 orang ( $20 \%$ ), sedangkan yang 40 mahasiswa ( $80 \%$ ) harus mengulang. Pada tahun 2011 dari mahasiswa 65 mahasiswa yang dinyatakan lulus ujian praktikum adalah 27 orang $(41,5 \%)$ sedangkan sisanya 38 orang $(58,5 \%)$ dinyatakan harus ujian ulang. Sedangkan pada tahun 2012, dari 55 mahasiswa yang dinyatakan lulus ujian adalah 24 orang ( $43,6 \%$ ), untuk sisanya 31 orang ( $56,4 \%$ ) harus mengikuti ujian ulang.

Pembelajaran praktikum yang dilakukan saat ini adalah dengan hanya melakukan demontrasi satu atau dua kali saja oleh dosen kepada mahasiswa, dan selanjutnya mahasiswa dianjurkan untuk melakukan praktik mandiri tanpa pengawasan dari seorang dosen, sehingga terkadang hanya beberapa orang saja yang benar-benar melakukan praktik mandiri sedangkan yang lain menganggap itu hanyalah hal yang mudah sehingga tidak melakukan praktek mandiri, melainkan hanya bertindak menjadi penonton saja Stikes guna bangsa Yogyakarta (2012).

Hasil prestasi belajar dari mahasiswa juga akan ditentukan dengan seberapa besar motivasi mahasiswa dalam mengikuti proses belajar, seseorang yang tidak mempunyai motivasi tidak akan mungkin melakukan aktivitas belajar dengan baik, sehingga hasil prestasi yang akan dicapai akan sangat kurang memuaskan (Djamarah, 2002).
Berdasarkan dari latar belakang tersebut diatas penulis tertarik untuk meneliti "Perbedaan self assessment dan peer assessment terhadap kompetensi pemasangan infus ditinjau dari motivasi“

\section{METODE PENELITIAN}

\section{A. Tempat dan Waktu Penelitian}

Penelitian ini akan dilaksanakan di Sekolah Tinggi IImu Kesehatan (STIKES) Guna Bangsa Yogyakarta pada Program Studi S1 Ilmu Keperawatan semester IV pada bulan Juli 2013.

\section{B. Jenis Penelitian}

Jenis penelitian adalah penelitian kuantitatif eksperimen, menggunakan pendekatan True eksperimen, dan memakai desain pretest-postest design.

C. Populasi, Sampel dan Tehnik Sampling Populasi dalam penelitian ini adalah mahasiwa Program Studi S1 IImu Keperawatan STIKES Guna Bangsa Yogyakarta semester IV sejumlah 60 mahasiswa. Sampel pada penelitian ini menggunakan semua populasi yang ada atau dengan cara exhaustive sampling, yaitu dengan menggambil seluruh populasi yang ada yang berjumlah 60 mahasiswa, sedangkan teknik pengambilan sampel untuk menentukan kelompok perlakuan dengan cara random sampling.

\section{Variabel Penelitian}

Variabel bebas / independent adalah model assessment dan motivasi. Variabel terikat / dependent adalah kompetensi pemasangan infus.

\section{E. Instrumen Penelitian}

Instrumen dalam penelitian ini menggunakan kuesioner untuk mengukur motivasi, dan menggunakan cek list standar operating prosedur (sop) untuk mengukur kompetensi pemasangan infus

F. Uji Validitas dan Reliabilitas

\section{Uji validitas}

Uji validitas setiap item instrumen motivasi menggunakan rumus Pearson Product Moment, Hasil uji validitas dari 30 soal, 27 soal valid dan 3 soal tidak valid.

\section{Uji Reliabilitas}

Hasil uji dari reliabilitas dengan rumus Alpha Crombath menunjukkan nilai 0,960, yang artinya bahwa instrumen sudah reliabel, karena hasil dari statistik melebihi nilai kriteria 0,6.

\section{G. Tehnik Analisis Data}

Analisis data penelitian menggunakan Anova dua jalur dengan bantuan komputer dan menggunakan program SPSS, sedangkan untuk mengetahui normalitas menggunakan uji kolmogorov smirnov. 


\section{HASIL DAN PEMBAHASAN}

A. Karakteristik Penelitian

1. Pendidikan Terakhir

Tabel 1. Karakteristik Responden Kelompok Peer Assessment berdasarkan pendidikan terakhir

\begin{tabular}{lll}
\hline Karakteristik & \multicolumn{2}{l}{ Nilai } \\
\cline { 2 - 3 } & $\mathrm{n}$ & $\%$ \\
\hline SMU ( IPA) & 15 & 50 \\
SMU ( IPS ) & 10 & 33.3 \\
SMK & 5 & 16.7 \\
Total & 30 & 100 \\
\hline
\end{tabular}

Berdasarkan tabel diskripsi responden pada kelompok perlakuan peer assessment dari 30 responden terdapat lulusan SMU jurusan IPA sebanyak 15 responden atau sebesar $50 \%$, lulusan SMU jurusan IPS sebanyak 10 responden atau sebesar 33,3\%, untuk lulusan sisanya sebanyak 5 responden atau sebesar $16,7 \%$ adalah lulusan dari SMK.

Tabel 2. Karakteristik Responden Kelompok Self Assessment berdasarkan pendidikan terakhir

\begin{tabular}{lll}
\hline Karakteristik & \multicolumn{2}{c}{ Nilai } \\
\cline { 2 - 3 } & $\mathrm{n}$ & $\%$ \\
\hline SMU ( IPA ) & 13 & 43.3 \\
SMU ( IPS ) & 11 & 36.7 \\
SMK & 6 & 20 \\
Total & 30 & 100 \\
\hline
\end{tabular}

Responden pada kelompok self assessment pada tabel diatas juga barjumlah 30 responden yang terdiri dari lulusan SMU jurusan IPA terdapat 13 responden atau $43,3 \%$, lulusan SMU jurusan IPS sebanyak 11 responden atau $36,7 \%$, dan sisanya adalah lulusan dari SMK sebanyak 6 responden atau $20 \%$.

\section{Umur}

Tabel 3.Karakteristik Responden Kelompok Peer Assessment berdasarkan umur

\begin{tabular}{lll}
\hline Karakteristik & \multicolumn{2}{l}{ Nilai } \\
\cline { 2 - 3 } & $\mathrm{n}$ & $\%$ \\
\hline 19 Tahun & 13 & 43.3 \\
20 Tahun & 11 & 36.7 \\
21 Tahun & 6 & 20 \\
Total & 30 & 100 \\
\hline
\end{tabular}

Berdasarkan dari karakteristik umupada tabel diatas dibagi menjadi tiga kelompok, yaitu kelompok umur 19 tahun, kelompok umur 20 tahun, dan kelompok umur 21 tahun, kelompok umur pada kelompok peer assessment terdiri dari 30 responden yang terdiri dari umur 19 tahun sebanyak 13 responden atau sebesar $43,3 \%$, umur 20 tahun sebanyak 11 responden atau sebesar $36,7 \%$, dan umur 21 tahu sebanyak 6 responden atau sebesar $20 \%$.

Tabel 4. Karakteristik Responden Kelompok Self Assessment berdasarkan umur

\begin{tabular}{lll}
\hline Karakteristik & Nilai \\
\cline { 2 - 3 } & $\mathrm{n}$ & $\%$ \\
\hline 19 Tahun & 14 & 46.7 \\
20 Tahun & 10 & 33.3 \\
21 Tahun & 6 & 20 \\
Total & 30 & 100 \\
\hline
\end{tabular}

Kelompok self assessment juga terdiri dari 30 responden yang terdiri dari umur 19 tahun sabanyak 14 responden atau sebesar $46,7 \%$, umur 20 tahun sebanyak 10 responden atau sebesar $33,3 \%$, dan umur 21 tahun sebanyak 6 responden atau sebesar $20 \%$.

\section{Kategori motivasi}

Tabel 5. Tingkat motivasi kelompok peer assessment

\begin{tabular}{llll}
\hline Motivasi & & $\mathrm{F}$ & $\%$ \\
\hline Valid & Rendah & 17 & 56.7 \\
& Tinggi & 13 & 43.3 \\
& Total & 30 & 100.0 \\
\hline
\end{tabular}

Motivasi kelompok peer assessment pada tabel 5 di bedakan menjadi motivasi rendah dengan jumlah 17 responden atau $56,7 \%$, dan motivasi tinggi dengan jumlah 13 responden atau $43,3 \%$

Tabel 6. Tingkat motivasi kelompok self assessment

\begin{tabular}{llll}
\hline Motivasi & & $\mathrm{F}$ & $\%$ \\
\hline Valid & Rendah & 14 & 46.7 \\
& Tinggi & 16 & 53.3 \\
& Total & 30 & 100 \\
\hline
\end{tabular}

Motivasi kelompok self assessment pada tabel 6 juga di bedakan menjadi motivasi rendah dengan jumlah 14 responden atau 46,7\%, dan motivasi tinggi dengan jumlah 16 responden atau $53,3 \%$.

\section{Kategori nilai}




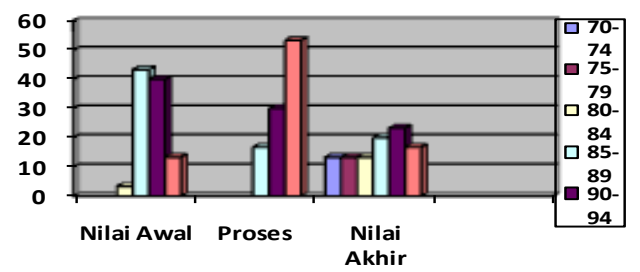

Gambar 1

Kategori nilai kelompok peer assessment

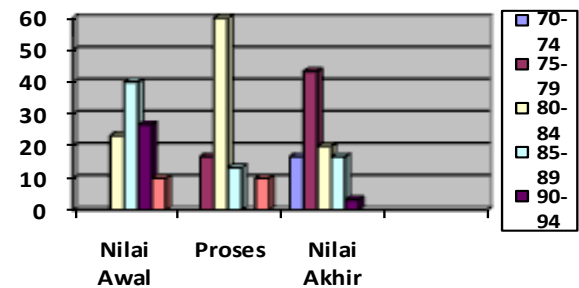

Gambar 2. Analisis nilai kelompok self assessment

Hasil analisis penilaian yang ada pada gambar 1 kelompok peer assessment di bagi menjadi tiga jenis yang dinilai yaitu, penilaian pada nilai awal, nilai antara 70-74, dan 75-79 menunjukkan tidak ada satupun responden yang memperoleh nilai tersebut atau mendapat nilai $0 \%$, untuk nilai antara $80-84$ menunjukkan ada 1 responden atau 3,3\%, nilai antara 85 - 89 terdapat 13 responden atau $43,3 \%$, nilai antara 90 - 94 terdapat 12 responden atau $40 \%$, dan nilai antara $95-99$ terdapat 4 responden atau 13,3\%.

Kelompok penilaian yang dilakukan pada saat proses, menunjukkan nilai antara $70-74$, $75-79,80-84$ tidak ada satupun responden yang mempunyai nilai tersebut atau mendapat nilai $0 \%$, nilai antara $85-89$ terdapat 5 responden atau $16,7 \%$, nilai antara $90-94$ terdapat 9 responden atau $30 \%$, nilai antara $95-99$ terdapat 16 responden atau $53,3 \%$.

Kelompok penilaian yang dilakukan pada nilai akhir menunjukkan nilai antara 70-74 terdapat 4 responden atau $13,3 \%$, pada kelompok ini dinyatakan tidak lulus atau mempunyai kompetensi pemasangan infus yang kurang karena nilainya tidak melebihi dari nilai 75 , pada nilai antara 75-79 terdapat 4 responden atau $13,3 \%$, pada nilai antara 80 84 juga terdapat 4 responden atau $13,3 \%$, pada nilai 85-89 terdapat 6 responden atau $20 \%$, pada nilai antara $90-94$ terdapat 7 responden atau $23,3 \%$, dan pada nilai antara 95-99 terdapat 5 responden atau 16,7\%.

Hasil penilaian kelompok self assessment pada gambar 2 juga dibedakan menjadi tiga kelompok, yaitu nilai awal dengan nilai antara 70-74, dan 74-79 tidak ada satupun responden yang mendapat nilai tersebut atau $0 \%$, pada nilai 80-84 terdapat 7 responden atau $23,3 \%$, pada nilai antara 85-89 terdapat 12 responden atau $20 \%$, pada nilai $90-94$ terdapat 8 responden atau $26,7 \%$, pada nilai antara $95-$ 99 terdapat 3 responden atau 10\%.

Kelompok penilaian pada saat proses nilai antara 70 - 74 tidak terdapat responden yang mendapatkan nilai tersebut atau nilai $0 \%$, pada nilai antara 75-79 terdapat 5 responden atau $16,7 \%$, pada nilai $80-84$ terdapat 18 responden atau $60 \%$, nilai antara $85-89$ terdapat 4 responden atau $13,3 \%$, pada nilai antara 90-94 tidak terdapat satu pun responden atau $0 \%$, dan pada nilai antara 9599 terdapat 3 responden atau 10\%.

Penilaian pada saat nilai akhir, nilai antara 70-74 terdapat 5 responden atau 16,7\% dan pada nilai ini mahasiswa dinyatakan tidak lulus atau kurang kompeten karena nilai kurang dari 75 , pada nilai antara 75-79 terdapat 13 responden atau $43,3 \%$, pada nilai antara 80-84 terdapat 6 responden atau $20 \%$, pada nilai antara 85-89 terdapat 5 responden atau $16,7 \%$, dan pada nilai antara 90-94 terdapat 1 responden atau 3,3\%, nilai antara 95-99 tidak terdapat satupun responden atau 0 $\%$.

\section{Uji Normalitas}

\begin{tabular}{lllll}
\hline Asses & & & & \\
ment & Motivasi & Mean & Std. Dev & $\mathrm{N}$ \\
\hline Peer & Rendah & 81.4706 & 7.53424 & 17 \\
& Tinggi & 91.7692 & 5.03577 & 13 \\
& Total & 85.9333 & 8.29180 & 30 \\
\hline Self & Rendah & 79.7143 & 5.53907 & 14 \\
& Tinggi & 79.5625 & 5.57337 & 16 \\
& Total & 79.6333 & 5.46136 & 30 \\
\hline Total & Rendah & 80.6774 & 6.66027 & 31 \\
& Tinggi & 85.0345 & 8.10416 & 29 \\
& Total & 82.7833 & 7.65150 & 60 \\
\hline
\end{tabular}

Tabel 7.Uji Normalitas 
Supaya data yang didapat memenuhi syarat untuk proses selanjutnya, maka pada penelitian ini menggunakan tes normalitas dengan menggunakan tes kolmogorovsmirnov, dan mendapatkan hasil pada tabel 7 yang menunjukkan hasil signifikasi pada kelompok peer assessment dan kelompok self assessment, kreteria signifikan diartikan apabila hasil menunjukkan nilai $p \geq 0,05$, yang mana pada hasil penilaian ini masing-masing menunjukkan angka yang signifikan.

\section{Motivasi dan Assessment}

Tabel 8

Motivasi dan assessment (nilai akhir)

Tabel 8 menunjukkan hasil dari masingmasing assessment yang mempunyai motivasi tingkat rendah ataupun tingkat tinggi, hasil kelompok peer assessment pada motivasi tinggi menunjukkan adanya nilai mean 91,7692 yang berjumlah 13 responden, untuk motivasi tingkat rendah mendapat nilai mean 81,4706 yang berjumlah 17 responden.

Kelompok self assessment dengan motivasi tinggi menunjukkan nilai mean 79,5625 yang berjumlah 16 responden, dan untuk motivasi tingkat rendah mendapat nilai mean 79,7143 dengan jumlah 14 responden.

\section{Peer assessment, self assessment dan motivasi ( nilai akhir)}

Tabel 9. Peer assessment, self assessment dan motivasi (nilai akhir)

\begin{tabular}{|c|c|c|c|c|}
\hline Source & $\mathrm{df}$ & $\begin{array}{l}\text { Mean } \\
\text { Square }\end{array}$ & $\mathrm{F}$ & Sig. \\
\hline Corrected Model & 3 & 458.949 & 12.372 & .000 \\
\hline Intercept & 1 & 410001.741 & 11052.656 & .000 \\
\hline Assesment & 1 & 722.967 & 19.489 & .000 \\
\hline Motivasi & 1 & 381.788 & 10.292 & .002 \\
\hline $\begin{array}{l}\text { Assesment } \\
\text { Motivasi }\end{array}$ & 1 & 404.974 & 10.917 & .002 \\
\hline Error & 56 & 37.095 & & \\
\hline Total & 60 & & & \\
\hline Corrected Total & 59 & & & \\
\hline
\end{tabular}

Analisis dengan menggunakan anova dua jalur dari tabel 9 yang dilakukan pada saat nilai akhir menunjukkan hasil assessment $\mathrm{p} 0,000$ atau mendapatkan nilai signifikan, yang dapat disimpulkan bahwa ada perbedaan antara peer assessment dan self assessment terhadap kompetensi pemasangan infus.

Tabel 9 pada motivasi menunjukkan hasil nilai p0,002 atau mendapatkan nilai

\begin{tabular}{lllll}
\hline & \multirow{2}{*}{\begin{tabular}{l} 
Ksses \\
\cline { 3 - 5 }
\end{tabular}} & Kolmogorov-Smirnov & \\
\cline { 3 - 5 } & Statistic & df & Sig. \\
\hline Nilai & Peer & .154 & 30 & .066 \\
Awal & Self & .148 & 30 & .090 \\
Nilai & Peer & .111 & 30 & .200 \\
Akhir & Self & .146 & 30 & .101
\end{tabular}

signifikan, yang dapat disimpulkan bahwa ada perbedaan antara motivasi tinggi dan motivasi rendah terhadap kompetensi pemasangan infus.

Assessment dan motivasi pada tabel 9 mendapatkan hasil nilai p 0,002 atau juga mempunyai nilai yang signifikan, yang dapat disimpilkan bahwa ada interaksi antara model assessment dan motivasi terhadap kompetensi pemasangan infus.

\section{Interaksi model assessment dan motivasi}

Tabel 10. Interaksi model assessment dan motivasi

\begin{tabular}{|c|c|c|c|c|c|}
\hline \multirow{3}{*}{$\begin{array}{l}\text { (I) } \\
\text { Interak } \\
\text { si }\end{array}$} & \multirow{3}{*}{$\begin{array}{l}\text { (J) } \\
\text { Intera } \\
\text { ksi }\end{array}$} & \multirow{3}{*}{$\begin{array}{l}\text { Mean } \\
\text { Difference } \\
\text { J) }\end{array}$} & \multirow[b]{3}{*}{ Sig. } & \multicolumn{2}{|c|}{ 95\% Confidence Interval } \\
\hline & & & & Lower & Upper \\
\hline & & & & Bound & Bound \\
\hline \multirow[t]{3}{*}{$A$} & $\mathrm{~B}$ & $-10.29864^{*}$ & .000 & -14.7939 & -5.8034 \\
\hline & C & 1.75630 & .428 & -2.6471 & 6.1597 \\
\hline & D & 1.90809 & .372 & -2.3417 & 6.1579 \\
\hline \multirow[t]{3}{*}{ B } & $A$ & $10.29864^{*}$ & .000 & 5.8034 & 14.7939 \\
\hline & C & $12.05495^{\star}$ & .000 & 7.3556 & 16.7543 \\
\hline & D & $12.20673^{*}$ & .000 & 7.6510 & 16.7625 \\
\hline \multirow[t]{3}{*}{$\mathrm{C}$} & $\mathrm{A}$ & -1.75630 & .428 & -6.1597 & 2.6471 \\
\hline & $\mathrm{B}$ & $-12.05495^{*}$ & .000 & -16.7543 & -7.3556 \\
\hline & D & .15179 & .946 & -4.3133 & 4.6169 \\
\hline \multirow[t]{3}{*}{$\mathrm{D}$} & $A$ & -1.90809 & .372 & -6.1579 & 2.3417 \\
\hline & $\mathrm{B}$ & $-12.20673^{*}$ & .000 & -16.7625 & -7.6510 \\
\hline & C & -.15179 & .946 & -4.6169 & 4.3133 \\
\hline
\end{tabular}

Keterangan:

A : Kelompok peer assessment dengan motivasi rendah

B : Kelompok peer assessment dengan motivasi tinggi

C : Kelompok self assessment dengan motivasi rendah

D : Kelompok self assessment dengan motivasi tinggi

Tabel 10 menunjukkan adanya hasil interaksi dari masing-masing kelompok model assessment dan motivasi terhadap kompetensi pemasangan infus. Nilai pada tabel 10 dikatakan signifikan apabila menunjukkan nilai $p \leq 0,05$, sedangkan nilai dikatakan tidak signifikan apabila nilai $\mathrm{p} \geq$ 0,05 . Hasil dari tabel 10 yang menunjukkan adanya interaksi dengan nilai p 0.000 atau signifikan adalah pada kelompok antara $A B$ atau BA yaitu kelompok peer assessment dengan motivasi tinggi dan kelompok peer assessment dengan motivasi rendah , kelompok BC atau CB yaitu kelompok peer assessment dengan motivasi tinggi dan kelompok self assessment dengan motivasi 
rendah, dan kelompok BD atau DB yaitu kelompok peer assessment dengan motivasi tinggi dan kelompok self assessment dengan motivasi tinggi.

Nilai hasil yang tidak signifikan pada tabel 10 antara lain terdapat pada kelompok AC atau CA yaitu kelompok peer assessment dengan motivasi rendah dan kelompok self assessment dengan motivasi rendah yang mendapat nilai $p 0,428$, kelompok $A D$ atau $D A$ yaitu kelompok peer assessment dengan motivasi rendah dan kelompok self assessment dengan motivasi tinggi yang mendapat nilai p 0,372, kelompok CD atau DC yaitu kelompok self assessment dengan motivasi rendah dengan self assessment dengan motivasi tinggi yang mendapat nilai $p$ 0,946 .

\section{B. Pembahasan}

Hasil penelitian untuk mengetahui perbedaan antara peer assessment dan self assessment terhadap kompetensi pemasangan infus pada saat nilai awal tidak menunjukkan adanya perbedaan yang bermakna atau mempunyai nilai $p 0,126$ yang mana nilai tersebut tidak signifikan, akan tetapi hasil pada saat penilaian akhir menunjukkan bahwa ada perbedaan yang bermakna antara self assessment dan peer assessment terhadap kopetensi pemasangan infus, ini ditunjukkan dengan nilai signifikan pada hasil analisisnya yaitu $p 0,000$.

Hasil dari penelitian untuk melihat perbedaan antara motivasi tinggi dan motivasi rendah terhadap kompetensi pemasangan infus pada saat nilai awal juga menunjukkan hasil yang tidak signifikan, atau memperoleh nilai p 0,357 atau dapat disimpulkan bahwa tidak ada perbedaan yang bermakna motivasi tinggi dan motivasi rendah terhadap kompetensi pemasangan infus, hasil analisis pada saat nilai akhir untuk melihat perbedaan motivasi tinggi dan motivasi rendah terhadap kompetensi pemasangan infus menunjukkan hasil nilai $p \quad 0,002$ yang artinya mempunyai nilai signifikan dan dapat disimpulkan ada perbedaan yang bermakna antara motivasi tinggi dan motivasi rendah terhadap kompetensi pemasangan infus.

Uji stastistik untuk mengetahui adanya interaksi antara model assessment dan motivasi terhadap kompetensi pemasangan infus pada saat nilai awal tidak mempunyai nilai yang bermakna, yaitu mendapat nilai $p$ 0,442 yang dapat disimpulkan bahwa tidak ada interaksi pada saat nilai awal, akan tetapi pada saat nilai akhir hasil stastistik menunjukkan nilai $p \quad 0,002$ atau mempunyai nilai yang signifikan, dan dapat disimpulkan pada saat nilai akhir menunjukkan adanya interaksi antara model assessment dan motivasi terhadap kompetensi pemasangan infus.

Hasil interaksi dari masing-masing kelompok model assessment dan motivasi terhadap kompetensi pemasangan infus pada tabel 10 yang menunjukkan adanya interaksi dengan nilai $p 0.000$ atau signifikan adalah pada kelompok antara $A B$ atau $B A$ yaitu kelompok peer assessment dengan motivasi tinggi dan kelompok peer assessment dengan motivasi rendah, kelompok $\mathrm{BC}$ atau $\mathrm{CB}$ yaitu kelompok peer assessment dengan motivasi tinggi dan kelompok self assessment dengan motivasi rendah, dan kelompok BD atau DB yaitu kelompok peer assessment dengan motivasi tinggi dan kelompok self assessment dengan motivasi tinggi.

Nilai hasil yang tidak signifikan pada tabel 10 antara lain terdapat pada kelompok $\mathrm{AC}$ atau CA yaitu kelompok peer assessment dengan motivasi rendah dan kelompok self assessment dengan motivasi rendah yang mendapat nilai $p 0,428$, kelompok $A D$ atau $D A$ yaitu kelompok peer assessment dengan motivasi rendah dan kelompok self assessment dengan motivasi tinggi yang

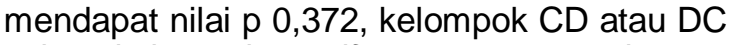
yaitu kelompok self assessment dengan motivasi rendah dengan self assessment dengan motivasi tinggi yang mendapat nilai $p$ 0,946 .

Hasil dari penelitian ini sesuai dengan teori menurut (Zulharman, 2007), yang mengungkapkan bahwa dengan peer assessment dan self assessment yang diterapkan pada saat pembelajaran di laboratorium maka akan dapat meningkatkan hasil prestasi belajar terhadap mahasiswa. Menurut (Puspasari, 2011) dalam penelitian yang dilakukannya, peer assessment dapat meningkatkan prestasi belajar siswa, dan peer assessment juga bisa dilaksanakan dalam proses belajar sebagai salah satu bentuk inovasi dalam melakukan kemampuan mahasiswa. Teori dari (Orsmond, 2004) juga menyebutkan bahwa self assessment juga meningkatkan kinerja atau kualitas dari belajar sehingga prestasi belajar mahasiswa dapat meningkat.

Variabel perbedaan motivasi yang juga mempunyai pengaruh yang bermakna terhadap kompetensi pemasangan infus, ini sesuai dengan teori menurut (Djamarah, 2002) bahwa seseorang yang tidak mempunyai motivasi tidak akan mungkin melakukan aktivitas belajar dan prestasi akademiknya dengan baik sehingga hasil dari prestasinya akan menjadi rendah akan tetapi sebaliknya, 
seseorang yang mempunyai motivasi yang tinggi, akan dengan baik melakukan aktivitas belajar dan memiliki prestasi akademik yang lebih baik. Penelitian ini juga sesuai dengan penelitian yang dilakukan oleh (Arini, 2008) yang meneliti tentang pengaruh motivasi belajar terhadap prestasi belajar yang dilakukan di SMA, hasil dari penelitiannya menyatakan bahwa dengan motivasi yang tinggi maka prestasi akademik dari mahasiswa akan mempunyai hasil yang lebih baik. Menurut (Rusdiana, 2011) yang juga meneliti tentang pengaruh motivasi belajar terhadap prestasi belajar di MTs mendapatkan hasil bahwa semakin besar motivasi mahasiswa maka akan semakin besar pula prestasi belajar mahasiswa. Arini (2008) dalam penelitiannya tentang motivasi belajar menunjukkan bahwa motivasi belajar sangat mempengaruhi hasil dari prestasi akademik mahasiswa.

Penelitian ini masih banyak kelemahan yang harus diperbaiki, beberapa kelemahan dari penelitian ini adalah tidak adanya kelompok kontrol, sehingga belum bisa membandingkan antara hasil penelitian yang ada saat ini dengan metode pembelajaran yang biasanya digunakan, selain itu keterbatasan jumlah responden yang hanya 60 responden juga manjadi suatu kelemahan dalam penelitian ini.

\section{Kesimpulan dan Saran}

A. Kesimpulan

1. Terdapat perbedaan yang bermakna antara self assessment dan peer assessment terhadap kompetensi pemasangan infus.

2. Terdapat perbedaan yang bermakna antara motivasi tinggi dan motivasi rendah terhadap kompetensi pemasangan infus.

3. Hasil dari interaksi yang diuji dengan uji anova terdapat sebagian interaksi yang bermakna yang memiliki nilai signifikan $\mathrm{p} \leq$ 0,05 dan ada sebagian yang tidak ada interaksi atau tidak mempunyai nilai signifikan dengan nilai $p \geq 0,05$.

B. Saran

1. Bagi Yayasan Stikes Guna Bangsa

Mengambil kebijakan untuk menerapkan metode pembelajaran ini sebagai alternatif untuk upaya peningkatan kualitas kompetensi mahasiswa S1 Keperawatan ataupun program studi yang lainnya.

2. Bagi Organisasi PPNI

Menekankan kepada organisasi PPNI yang berada di lingkup pendidikan untuk mencoba menerapkan metode pembelajaran ini sebagai alternatif pilihan agar tercapai konpetensi keperawatan yang lebih baik

3. Bagi Dosen

Bagi dosen yang belum mencoba metode pembelajaran ini, agar dapat mempelajari metode ini serta dapat mencoba menerapkannya pada konpetensikompetensi keperawatan yang lainnya.

\section{Daftar Pustaka}

AIPNI, 2008. Kurikulum Pendidikan Sarjana Keperawatan. Jakarta: Asosiasi pendidikan Sarjana Keperawatan

--------, 2010. Kurikulum Pendidikan Ners di Indonesia. Jakarta: Asosiasi Pendidikan Ners Indonesia

Bostock, S. 2001. Student peer assessment. [Internet]. Available from: $<$ http://www.keele.ac.uk/depts/aa/landt/lt/docs/ bostock peer assessment.ht $m>[12$ Maret 2013]

Boud, D. 1995. Enhancing Learning through Self Assessment. London:Kogan Page/SEDA

Bround, Phillips, Lauder, H. 1994. Education Policy. London:Kogan Page.

Brunner, L \& Suddarth, D. $2002 . \quad B u k u$ Ajar Keperawatan Medical Bedah. Jakarta: $\quad$ EGC

Cherniss, C \& Goleman, D. 2001. The emotionally intelligent workplace. San

Francisco: JosseyBass

Dimyati \& Mudjiono, 2006. Belajar dan Pembelajran. Jakarta: PT Rajagrafindo Persada.

Djamarah, SB. 2002. Psikologi belajar. Jakarta: PT Rineka Cipta.

Ellis, J.R. 1996. Modules for Basic Nursing Skills. Lippincot: Philadelphia

Isaacs, G. 1999. Peer and self assessment. London: Brief briefing

Jemes, H., Millan, M., Hearn, J. 2008. Student Self-Assessment The Key to Stronger Student Motivation and Higher Achievement. Hal 42-48. Education Horizon: Virginia 
Murti, B. 2006. Desain dan ukuran sampel untuk penelitian kuantitatif dan kualitatif di bidang kesehatan. Yogyakarta : Gadjah Mada University Press

Nazzal, A. 2001. Peer and Self-Assessment: 20 Classroom Strategies and Other Resources to Increase Student Motivation and Achievement. SCMSA Journal

Nursalam. 2008. Konsep Dan Penerapan Metodologi Penelitian IImu Keperawatan, Edisi 2. Jakarta :Penerbit Salemba Medika

Orsmond. 2004. Self and Peer Assessment Guidance on Practice in the Biosciences. London: Kogan Page

Race, P. 1998. Practical Pointers in Peer Assessment. Birmingham: SEDA

Siagian \& Sugiarto. 2006. Metode Statistika untuk bisnis dan ekonomi. Jakarta: PT Gramedia Pustaka Utama

Stikes Guna Bangsa Yogyakarta. 2012. Rekap Nilai Prodi Keperawatan. Yogyakarta

Spiller \& Dorothy. 2009. Assessment Matters: Self-Assessment and PeerAssessment.[Online].Tersedia:www.waika to.ac.nz/tdu/pdf/booklets/8_Self

PeerAssessmet.pdf. [9 Maret 2013]
Suwandi, S. 2009. Model Assesmen Dalam Pembelajaran. Surakarta: Mata Padi Presindo

Syamsudin, A. 1996. Psikologi Kependidikan. Bandung: PT Remaja Rosda Karya.

Thomas, G., Martin, D., Pleasant, K. 2011.

Using self- and peer- assessment to enhance students' futurelearning in higher education. Volume 8 issue 1 . Journal of University Teaching \& Learning

Practice.

Wilson, T.D. 2002. The Nonsense of Knowledge Management. Boston:Harvard Business School Press

Yety. 2012. Buku Panduan Praktikum skill lab GB. Modul Stikes Guna Bangsa

Zariski, A. 1996. Student peer assessment in tertiary education. Proceedings of the 5th Annual Teaching Learning Forum. Murdoch University

Zulharman. 2007. Self dan Peer Assessment sebagai Penilaian Formatif dan Sumatif.http://zulharman79.wordpress.com [15 Februari 2013] 